established coronary heart disease. In RA it has been investigated by carotid artery ultrasound and carotid atherosclerotic plaques are more prevalent in RA patients than controls. EULAR recommendations for cardiovascular disease risk management consider that carotid ultrasound may be part of the risk evaluation in patients with RA. Recent studies in general population have shown that plaques in femoral arteries are more common and are associated with higher cardiovascular risk.

Objectives: To study the usefulness of femoral artery ultrasound for the detection of subclinical atherosclerosis and its ability to improve cardiovascular risk assessment in RA patients.

Methods: Cross-sectional observational study of prevalence in 140 RA patients aged 40 to 65 years. Subclinical atherosclerosis was evaluated by carotid and femoral artery ultrasound.

Results: Atherosclerotic plaques were found in $86.4 \%$ of RA patients $(60.7 \%$ in carotid arteries and $78.6 \%$ in femoral arteries). Patients with plaques were older and more frequently past or present tobacco users. Femoral plaques were larger and more numerous than the carotid plaques and people with plaques in both locations had more extensive subclinical atherosclerotic disease (table). Only $7.9 \%$ of RA patients were considered as having very high cardiovascular risk by clinical factors, after carotid ultrasound this increased to $57.1 \%$ and after femoral ultrasound to $86.4 \%$.

Conclusion: Ultrasound examinations of the femoral artery in addition to the carotid artery increased the detection of subclinical atherosclerosis and determine a group of patients with higher intensity of atherosclerotic disease. Examinations of both arteries allowed a greater number of RA patients previously considered to have low to moderate cardiovascular risk to be classified as very high cardiovascular risk.

References:

[1] Agca R, Heslinga SC, Rollefstad S, Heslinga M, Mclnnes IB, Peters MJL, et al. EULAR recommendations for cardiovascular disease risk management in patients with rheumatoid arthritis and other forms of inflammatory joint disorders: 2015/2016 update. Ann Rheum Dis. 2017 Jan;76(1):17-28.

[2] Ambrosino P, Lupoli R, Di Minno A, Tasso M, Peluso R, Di Minno MND. Subclinical atherosclerosis in patients with rheumatoid arthritis. A meta-analysis of literature studies. Thromb Haemost. 2015 May;113(5):916-30.

[3] Laclaustra M, Casasnovas JA, Fernández-Ortiz A, Fuster V, León-Latre M, Jiménez-Borreguero LJ, et al. Femoral and Carotid Subclinical Atherosclerosis Association With Risk Factors and Coronary Calcium: The AWHS Study. J Am Coll Cardiol. 2016 Mar 22;67(11):1263-74.

Table

\begin{tabular}{|c|c|c|c|}
\hline & $\begin{array}{c}\text { Only carotid } \\
\text { plaques } \\
n=11\end{array}$ & $\begin{array}{l}\text { Only femoral } \\
\text { plaques } \\
n=36\end{array}$ & $\begin{array}{c}\text { Femoral and } \\
\text { carotid plaques } \\
\qquad n=74\end{array}$ \\
\hline Number of carotid plaques per patient & $1,3 \pm 0,5$ & - & $2,5 \pm 2,0^{*}$ \\
\hline Carotid plaques size $(\mathrm{mm})$ & $1,63 \pm 0,20$ & - & $2,08 \pm 0,69^{\star}$ \\
\hline Number of femoral plaques per patient & - & $2,3 \pm 1,7$ & $3,7 \pm 2,9^{\star *}$ \\
\hline Femoral plaque size $(\mathrm{mm})$ & - & $2,20 \pm 0,59$ & $3,10 \pm 1,10^{\star *}$ \\
\hline Total number of plaques per patient & $1,3 \pm 0,5$ & $2,3 \pm 1,7^{\star}$ & $6,2 \pm 4,3^{\star \star \star}$ \\
\hline
\end{tabular}

†Results in mean \pm sd. ${ }^{*} \mathrm{p}<0,05$ vs only carotid plaques. ${ }^{* *} \mathrm{p}<0,05$ vs only femoral plaques. ${ }^{* *} p<0,05$ vs only carotid plaques and only femoral plaques.

Disclosure of Interests: Julio Medina: None declared, Francisco Aramburu: None declared, Carmen González Montagut: None declared, Dolores Sánchez: None declared, Estíbaliz Loza Grant/research support from: Roche, Pfizer, Abbvie, MSD, Novartis, Gebro, Adacap, Astellas, BMS, Lylly, Sanofi, Eisai, Leo, Sobi DOI: 10.1136/annrheumdis-2020-eular.2378

\begin{tabular}{|l|l}
\hline OP0123 & RISK OF BREAST CANCER BEFORE AND AFTER \\
RHEUMATOID ARTHRITIS, AND THE IMPACT OF \\
HORMONAL FACTORS
\end{tabular}

H. Wadström ${ }^{1}$, A. Pettersson ${ }^{1}$, K. Ekström Smedby ${ }^{1}$, J. Askling ${ }^{1} .{ }^{1}$ Karolinska Insitutet, Department of Medicine, Solna, Stockholm, Sweden

Background: Large cohort studies have consistently reported decreased occurrence of breast cancer among women with RA. However, both the reasons behind this decreased risk and if it is present already before RA diagnosis, is unclear. The occurrence of RA following breast cancer is clinically and etiologically important also for other reasons. Long-term adjuvant anti-hormonal treatment with tamoxifen or aromatase inhibitors has become mainstay for estrogen receptor positive breast cancer, but are often associated with arthralgia as a side effect. Some studies have suggested that these therapies not only induce arthralgia, but also inflammatory arthritis.
Objectives: To examine the risk of incident breast cancer in women with RA, and the risk of RA in women with a history of breast cancer, taking anti-hormonal treatment for breast cancer into account.

Methods: Using nationwide Swedish registers, women with new-onset RA diagnosed 2006-2016 were identified. Each RA patient was matched on age, sex, and place of residence to 5 randomly selected control subjects from the general population. Through register linkages, we collected information on breast cancer, breast cancer risk factors (age at childbirth, number of children, hormone replacement therapy), and socio-economy. The relative risk of breast cancer after RA was assessed using Cox regression, and the relative risk of RA in women with a history of breast was assessed using conditional logistic regression.

Results: The risk of incident breast cancer in women with RA was reduced and the association was not attenuated by adjustment for breast cancer risk factors $(\mathrm{HR}=0.80,95 \% \mathrm{Cl} 0.68-0.93)$ (Table 1$)$. The risk was similar among seronegative $\mathrm{RA}$, (HR=0.77, 95\% $\mathrm{Cl}$ 0.58-1.02), and seropositive RA, $(\mathrm{HR}=0.81,95 \% \mathrm{Cl}, 0.67$ 0.98 ), and for all age groups. We noted reduced risks for all TNM stages, and for both pre- and postmenopausal breast cancer (assessed with age cutoff 50 years). The risk of RA in women with a history of breast cancer was similarly reduced $(\mathrm{OR}=0.87,95 \% \mathrm{Cl}, 0.79-0.95)$. Odds ratios $(\mathrm{OR})$ stratified by serostatus and age at RA diagnosis yielded similar results. There was no clear trend in the level of risk reduction when examining the risk by menopausal status, or cancer stage at breast cancer diagnosis. Women with breast cancer treated with tamoxifen $(\mathrm{OR}=0.86,95 \% \mathrm{Cl} 0.62-1.20)$, or aromatase inhibitors $(\mathrm{OR}=0.97$, $95 \% \mathrm{Cl} 0.69-1.37$ ), did not have an increased risk of RA compared to women with breast cancer treated differently.

Table 1. Risk of breast cancer in women with RA, overall and by serostatus (events and hazard ratios), and risk of RA in women with a history of breast cancer, overall and by serostatus (events and odds ratios)

\begin{tabular}{lccc}
\hline & $\begin{array}{c}\text { No. of breast } \\
\text { cancers, patients } \\
\text { with RA }\end{array}$ & $\begin{array}{c}\text { No. of breast can- } \\
\text { cers, comparators/ } \\
\text { controls }\end{array}$ & RR (95\% Cl) \\
\hline $\begin{array}{l}\text { Risk of breast cancer in } \\
\text { women with RA }\end{array}$ & 190 & 1191 & $0.80(0.68-0.93)$ \\
$\begin{array}{l}\text { Seronegative RA } \\
\text { Seropositive RA }\end{array}$ & 55 & 346 & $0.77(0.58-1.02)$ \\
$\begin{array}{l}\text { Risk of RA in women } \\
\text { with breast cancer }\end{array}$ & 124 & 772 & $0.81(0.67-0.98)$ \\
$\begin{array}{l}\text { Seronegative RA } \\
\text { Seropositive RA }\end{array}$ & 555 & 3193 & $0.87(0.79-0.95)$ \\
& 157 & 921 & $0.85(0.71-1.01)$ \\
& 367 & 2088 & $0.88(0.78-0.98)$
\end{tabular}

Conclusion: There is a decreased risk of breast cancer in patients with RA and a similar decrease in risk of breast cancer before RA diagnosis. We did not find evidence to support that the decreased risk of breast cancer was due to known risk determinants. Furthermore, adjuvant anti-hormonal therapy as used in secondary breast cancer pharmacoprevention did not seem to increase the risk of RA.

Disclosure of Interests: Hjalmar WADSTRÖM: None declared, Andreas Pettersson: None declared, Karin Ekström Smedby: None declared, Johan Askling Grant/research support from: JA acts or has acted as PI for agreements between Karolinska Institutet and the following entities, mainly in the context of the ARTIS national safety monitoring programme of immunomodulators in rheumatology: Abbvie, BMS, Eli Lilly, Merck, MSD, Pfizer, Roche, Samsung Bioepis, Sanofi, and UCB Pharma

DOI: 10.1136/annrheumdis-2020-eular.3280

\section{OP0124 RISK OF MALIGNANCIES ACROSS BIOLOGIC CLASSES IN RHEUMATOID ARTHRITIS: ANALYSIS OF A NATIONAL CLAIM DATABASE}

R. Seror ${ }^{1}$, B. Fautrel ${ }^{2}$, A. Lafourcade ${ }^{2}$, Y. De-Rycke ${ }^{2}$, X. Mariette ${ }^{1}$, F. Tubach ${ }^{2}$. ${ }^{1}$ Hopitaux Universitaires Paris-Saclay, Rheumatology, Le Kremlin-Bicêtre, France, ${ }^{2}$ Pitié-Salpêtrière Hospital, Paris, France

\section{Background:}

Objectives: To estimate the incidence rate of malignancies in biologic-treated RA patients, and to compared it to the general population and across different classes of biologics

Methods: We conducted an historical cohort study within the French the national claim database, named SNDS. This database prospectively records individual health resource of $86 \%$ of the entire French population (65 million inhabitants) since 2007. RA adult patients were identified based on ICD-10 code (M05 or M06). Patients with cancer history were excluded. Treatment exposures focused on incident first use of biologics including all anti-TNF, rituximab, abatacept, tocilizumab, ustekinumab, anakinra. To identify incident treatment periods, only patients who did not receive any biologics in the 1-year period before the index date were 
selected. In the base case analysis, exposure was defined with a 90-day latency after treatment initiation and a 180-day carry-over period after drug discontinuation. To compare the risk of malignancies between biologic treated patients and general population, Standardized incidence ratio (SIR $[95 \% \mathrm{CI}]$ ) were calculated using FRANCIM ("France Cancer Incidence et Mortalité") estimations as reference. To compare the risk of malignancies between biologics, a propensity score (including age, sex, year of first occurrence of RA code, date of treatment initiation, number of previous DMARDs, Charlson comorbidity index, diagnosis of tobacco and/or alcohol-associated disorders, number of hospitalizations for RA, cumulative corticosteroid dose) was calculated for each comparison. Hazard Ratios (HRs) for risk of cancer were estimated using Cox proportional hazard model using inverse probability of treatment weighting (IPTW) with propensity score. Exposure was considered as a time-dependent variable and propensity scores were estimated dynamically using pooled logistic regression reassessed for each new exposure.

Results: Between 2007 and 2016, 31,792 patients (112,802 patient-years)- were exposed to biologics. The annual incidence rate of overall malignancies was 0.865 per 100 patients-years. Malignancies occurred in 730 patients exposed to anti-TNF, 235 patients exposed to another biologic and 11 exposed to both As compared to the general population, biologic treated patients had an increased risk of lung cancer (SIR=1.35 [1.14;1.60]), a decreased risk of pancreatic cancer $(\mathrm{SIR}=0.52[0.31-0.85])$ and no significant increased risk of invasive melanoma $(\mathrm{SIR}=1.15[0.82 ; 1.61])$. Results were similar for anti-TNF-treated patients. Other biologics were not analyzed separately due to small sample sizes.

The overall risk of malignancies and risk of lymphoma did not differ between anti-TNF and other biologics (analysed all together), or abatacept. Within the anti-TNF class, the overall risk of malignancies and risk of lymphoma did not differ between etanercept and monoclonal anti-TNF (table).

\begin{tabular}{|c|c|c|c|c|c|c|}
\hline $\begin{array}{l}\text { Type of } \\
\text { malignancies }\end{array}$ & $\begin{array}{c}\mathrm{HR} \\
{[95 \% \mathrm{Cl}]}\end{array}$ & p-value & $\begin{array}{c}\mathrm{HR} \\
{[95 \% \mathrm{Cl}]}\end{array}$ & $\mathrm{p}$-value & $\begin{array}{c}\mathrm{HR} \\
{[95 \% \mathrm{Cl}]}\end{array}$ & p-value \\
\hline & $\begin{array}{l}\text { Anti-TNF } \\
\text { (ref) vs. } \\
\text { other } \\
\text { biologics }\end{array}$ & & $\begin{array}{l}\text { Anti-TNF } \\
\text { (ref) vs. } \\
\text { Abatacept }\end{array}$ & & $\begin{array}{l}\text { Monoclonal } \\
\text { anti-TNF } \\
\text { (ref) vs. } \\
\text { Etanercept }\end{array}$ & \\
\hline$P-Y$ exposure & $\begin{array}{c}83256 \text { vs. } \\
25649\end{array}$ & & $\begin{array}{c}91770 \text { vs. } \\
4681\end{array}$ & & $\begin{array}{c}49620 \text { vs. } \\
36790\end{array}$ & \\
\hline $\begin{array}{l}\text { All malignancies (excl. } \\
\text { non-melanoma } \\
\text { skin cancer) }\end{array}$ & $\begin{array}{c}0.97 \\
{[0.81 ; 1.17]}\end{array}$ & $\mathrm{p}=0.7$ & $\begin{array}{c}1.27 \\
{[0.89 ; 1.81]}\end{array}$ & $\mathrm{p}=0.2$ & $\begin{array}{c}1.11 \\
{[0.94 ; 1.32]}\end{array}$ & $\mathrm{p}=0.2$ \\
\hline $\begin{array}{l}\text { Solid cancer (excl. } \\
\text { non-melanoma } \\
\text { skin cancer) }\end{array}$ & $\begin{array}{c}0.98 \\
{[0.80 ; 1.20]}\end{array}$ & $\mathrm{p}=0.8$ & $\begin{array}{c}1.23 \\
{[0.84 ; 1.82]}\end{array}$ & $p=0.4$ & $\begin{array}{c}1.10 \\
{[0.92 ; 1.32]}\end{array}$ & $p=0.3$ \\
\hline Lymphoma & $\begin{array}{c}0.69 \\
{[0.32 ; 1.46]}\end{array}$ & $\mathrm{p}=0.3$ & $\begin{array}{c}1.73 \\
{[0.55 ; 5.48]}\end{array}$ & $\mathrm{p}=0.5$ & $\begin{array}{c}0.87 \\
{[0.49 ; 1.57]}\end{array}$ & $\mathrm{p}=0.7$ \\
\hline
\end{tabular}

Conclusion: Using a large nationwide healthcare database, representative of the French population, the overall risk of malignancies did not seem to differ across the different classes of biologic. Among anti-TNF, the risk of malignancies of lymphoma did not differ between etanercept and monoclonal antibodies. The risk of organ specific cancers, except lung cancer, did not differ from that of general population. Disclosure of Interests: Raphaèle Seror Consultant of: BMS, Medimmune, Novartis, Pfizer, GSK, Lilly, Bruno Fautrel Grant/research support from: AbbVie, Lilly, MSD, Pfizer, Consultant of: AbbVie, Biogen, BMS, Boehringer Ingelheim, Celgene, Lilly, Janssen, Medac MSD France, Nordic Pharma, Novartis, Pfizer, Roche, Sanofi Aventis, SOBI and UCB, Alexandre Lafourcade: None declared, yann de-rycke: None declared, Xavier Mariette Consultant of: BMS, Gilead, Medimmune, Novartis, Pfizer, Servier, UCB, Florence Tubach Grant/research support from: Florence TUBACH is head of the Centre de Pharmacoépidémiologie (Cephepi) of the Assistance Publique - Hôpitaux de Paris and of the Clinical Research Unit of Pitié-Salpêtrière hospital, both these structures have received research funding, grants and fees for consultant activities from a large number of pharmaceutical companies, that have contributed indiscriminately to the salaries of its employees. Florence Tubach didn't receive any personal remuneration from these companies. DOI: 10.1136/annrheumdis-2020-eular.3687

\section{OP0125 \\ LYMPHOMAS COMPLICATING RHEUMATOID ARTHRITIS: RESULTS OF A FRENCH MULTI-CENTRE CASE-CONTROL STUDY}

J. Kedra $^{1,2}$, R. Seror ${ }^{1,2}$, P. Dieudé ${ }^{2}$, A. Constantin ${ }^{2}$, E. Toussirot ${ }^{2}$, E. Kfoury ${ }^{2}$, C. Masson ${ }^{2}$, D. Cornec ${ }^{2}$, J. J. Dubost ${ }^{2}$, L. Marguerie ${ }^{2}$, S. Ottaviani ${ }^{2}$, F. Grados ${ }^{2}$, R. Belkhir ${ }^{1,2}$, O. Fain ${ }^{2}$, P. Goupille ${ }^{2}$, C. Sordet ${ }^{2}$, B. Fautrel ${ }^{2}$, P. Philippe ${ }^{2}$, M. Piperno ${ }^{2}$, B. Combe ${ }^{2}$, O. Lambotte ${ }^{2}$, C. Richez ${ }^{2}$, J. Sellam², T. Sene ${ }^{2}$, G. Denis ${ }^{2}$, T. Lequerre ${ }^{2}$, X. Mariette ${ }^{1,2}, \mathrm{G}$. Nocturne ${ }^{1,2} .^{1}$ AP-HP, Rheumatology Department, Bicetre Hospital, Le Kremlin-Bicêtre, France; ${ }^{2}$ CRI-IMIDIATE Network, Paris, France
Background: Rheumatoid arthritis (RA) is associated with an increased risk of non-Hodgkin B-cell lymphoma (B-cell NHL).

Objectives: 1)To study the characteristics of B-cell NHL complicating RA 2)To identify the factors associated with their occurrence.

Methods: A multi-centre case-control study was performed in France. Cases were patients with RA fulfilling the ACR-EULAR 2010 criteria, who developed a B-cell NHL after the diagnosis of RA. Cases were reported following a call for observations by the "Club Rhumatismes et Inflammation" network, registries from the French society of Rheumatology (AIR, ORA and REGATE) and the ESPOIR cohort. For each case, 2 control patients were drawn at random from patients in the ESPOIR cohort with RA fulfilling the ACR-EULAR 2010 criteria; cases and controls were matched on age (age at lymphoma diagnosis for cases and age at the 10-year ESPOIR visit for controls). Patients with associated Sjögren's syndrome were excluded. Cases and controls characteristics were compared for parameters associated with the occurrence of lymphoma

Results: A total of 54 cases were included and matched to 108 controls. Lymphomas were mostly diffuse large B-cell lymphomas $(n=26,48.2 \%)$ (Fig ure 1). EBV positivity was found in 4 cases among 27 tested (14.8\%). Cases had a mean age of 63.5 years $(S D=10.9)$, and had a mean $R A$ duration of 12.4 years $(S D=10.5)$ at the time of diagnosis of lymphoma; there was no significant difference with controls $(p=0.47$ and $p=0.40$ respectively). The mean duration of follow-up after the diagnosis of lymphoma was 5.2 years $(S D=5.8)$. In univariate analysis, factors associated with occurrence of B-cell $\mathrm{NHL}$ were: male gender $(\mathrm{OR}=3.3,95 \% \mathrm{Cl}$ : 1.7-6.7), positive ACPA (OR=5.1, $95 \% \mathrm{Cl}$ : 2.0-15.7), positive Rheumatoid Factor (RF) (OR=3.9, 95\% $\mathrm{Cl}=1.6$ 12.2), erosions on $X$-rays $(\mathrm{OR}=15.4,95 \% \mathrm{Cl}: 6.9-37.7)$ and DAS28 $(\mathrm{OR}=2.0$ $95 \% \mathrm{Cl}: 1.5-2.7)$. Methotrexate, TNF-blockers and the number of previous biologics were not associated with the occurrence of B-cell NHL. Hydroxychloroquine and sulfasalazine were more frequent in cases versus control, which could be linked to a date bias. Erosions and DAS28 remained significant in multivariate analysis (Table 1).

Conclusion: This study revealed an association between markers of activity (DAS28), severity (erosions) and autoimmune B-cell activation (RF and ACPA) and the risk of $\mathrm{B}$-cell $\mathrm{NHL}$ in patients with $\mathrm{RA}$, supporting the continuum between autoimmunity and lymphomagenesis in RA.

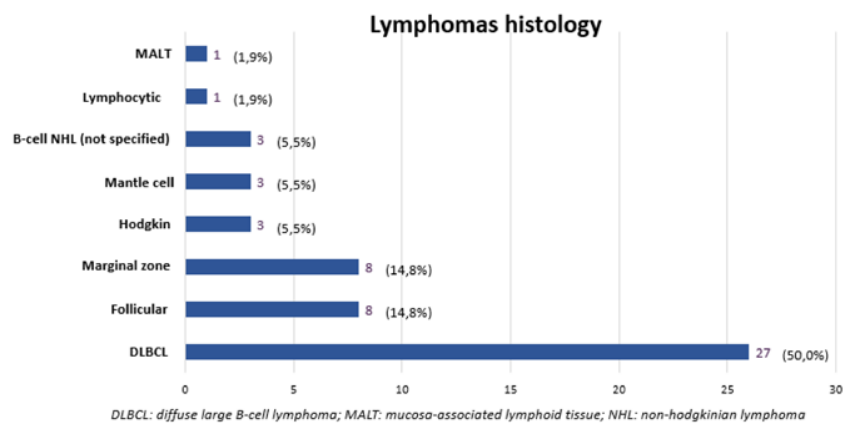

Figure 1. lymphomas histology

Table 1. association between RA characteristics and B-cell NHL in univariate and multivariate analysis

\begin{tabular}{|c|c|c|c|c|c|c|}
\hline \multirow[t]{2}{*}{ Variables } & \multirow{2}{*}{$\begin{array}{l}\text { Cases } \\
(\mathrm{N}=54)\end{array}$} & \multirow{2}{*}{$\begin{array}{l}\text { Controls } \\
(\mathrm{N}=108)\end{array}$} & \multicolumn{2}{|c|}{ Univariate analysis } & \multicolumn{2}{|c|}{ Multivariate analysis } \\
\hline & & & OR $(95 \% \mathrm{Cl})$ & $p$-value & OR $(95 \% \mathrm{Cl})$ & ) p-value \\
\hline Male gender, $\mathrm{N}(\%)$ & $27(50.0)$ & $25(23.2)$ & $\begin{array}{c}3.3 \\
(1.7-6.7)\end{array}$ & 0.0006 & $\begin{array}{c}2.2 \\
(0.8-6.1)\end{array}$ & 0.13 \\
\hline Positive ACPA, N (\%) & $49(90.7)$ & $71(65.7)$ & $\begin{array}{c}5.1 \\
(2.0-15.7)\end{array}$ & 0.0006 & - & - \\
\hline Positive RF, N (\%) & $49(90.7)$ & 77 (71.3) & $\begin{array}{c}3.9 \\
(1.6-12.2)\end{array}$ & 0.005 & - & - \\
\hline $\begin{array}{l}\text { Positive RF or ACPA, } \\
\quad \mathrm{N}(\%)\end{array}$ & $49(90.7)$ & $80(74.1)$ & $\begin{array}{c}3.4 \\
(1.3-10.6)\end{array}$ & 0.01 & $\begin{array}{c}2.9 \\
(0.7-15.0)\end{array}$ & 0.16 \\
\hline $\begin{array}{l}\text { Erosions on X-rays, } \\
\qquad \mathrm{N}(\%)\end{array}$ & 44 (81.5) & $26(24.1)$ & $\begin{array}{c}15.4 \\
(6.9-37.7)\end{array}$ & $<0.0001$ & $\begin{array}{c}9.8 \\
(3.8-28.2)\end{array}$ & $\begin{array}{c}< \\
0.0001\end{array}$ \\
\hline $\begin{array}{l}\text { DAS28 at B-cell NHL } \\
\text { diagnosis/at the } \\
\text { 10th year visit" } \\
\text { mean(SD) }\end{array}$ & $4.1(1.6)$ & $2.6(1.4)$ & $\begin{array}{c}2.0 \\
(1.5-2.7)\end{array}$ & $<0.0001$ & $\begin{array}{c}1.9 \\
(1.3-2.8)\end{array}$ & 0.0007 \\
\hline
\end{tabular}

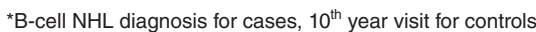

Disclosure of Interests: Joanna KEDRA: None declared, Raphaèle Seror Consultant of: BMS UCB Pfizer Roche, Philippe Dieudé: None declared, Arnaud Constantin: None declared, ERIC TOUSSIROT: None declared, Elias Kfoury: None 